\title{
Assessing the impact of resource efficiency on selected case studies in Ireland
}

\author{
Jan Göttsche BSc, MSC, PhD \\ Lecturer, Department of Building and Civil Engineering, Galway Mayo \\ Institute of Technology, Galway, Ireland (corresponding author: \\ jangottsche@yahoo.ie) (Orcid:0000-0002-0595-2348)
}

\author{
Mark Kelly BSc, MA, MSc (Research), PhD \\ Lecturer, Department of Building and Civil Engineering, \\ Galway Mayo Institute of Technology, Galway, Ireland \\ (Orcid:0000-0002-8209-1473)
}

In the EU, construction and the use of buildings account for $\mathbf{5 0 \%}$ of final energy consumption, approximately $\mathbf{3 5 \%}$ of greenhouse gas emissions, more than $\mathbf{5 0 \%}$ of all extracted materials, $\mathbf{3 0} \%$ of water consumption by the population and $35 \%$ of total generated waste, annually. In Ireland, there has been a clear connection between construction output, construction and demolition production and energy use. During this time of economic recovery, there is a unique opportunity to decouple this connection and rethink the built environment to one that embraces material cycles that have net positive environmental benefits. This study used an action research methodology to benchmark the effectiveness of implementing a series of resource efficiency measures during the construction phase of four case studies with a small-to-medium enterprise building contractor. The implementation of these measures in the case studies produced cost savings of $€ 14567.70$ representing $0.48 \%$ of the total project value ( $€ 3050032)$. The total energy savings were estimated to be $11373.09 \mathrm{kWh}$ and it was estimated that $176.751 \mathrm{t}$ of materials were prevented from being placed in site skips. The total reduction in carbon dioxide $\left(\mathrm{CO}_{2}\right)$ emissions from the implemented measures was $52.263 \mathrm{t}$.

\section{Introduction}

In the European Union (EU), the construction and operation of buildings are estimated to account for $40 \%$ of final energy consumption, $35 \%$ of greenhouse gas (GHG) emissions, more than $50 \%$ of all extracted materials (approximately 3 billion $\mathrm{t}$ in the EU), $30 \%$ of water consumption by the population and $35 \%$ of total generated waste, annually (EC, 2014a). Construction and demolition waste $(C \& D W)$ production in Ireland has seen remarkable fluctuations over the past 10 years, hitting a peak of $17.8 \mathrm{Mt}$ in 2007 followed by a dramatic decline to just over $3 \mathrm{Mt}$ in 2011 and an increase to the most recent estimate of 4.7 Mt in 2017 (EPA, 2020). This trend has reflected the unsustainable economic growth and decline over this period and has clearly highlighted the direct correlation between construction output and increased environmental impacts. Despite these recent lower estimates, C\&DW continues to be one of the largest waste streams in Ireland, almost $68 \%$ greater than municipal waste, the value for which in 2017 was $2.8 \mathrm{Mt}$ (EPA, 2020). It is clear from these figures that this mode of consumption and waste production is not sustainable in the long term and so, in this time of continued economic recovery, there is an opportunity to move towards a more efficient use of resources that will also reduce the environmental pressures associated with the different phases of the building life cycle. EU policy and legislation has highlighted the need of moving towards a more resource-efficient society through a series of regulatory and strategic documents focusing on: the sustainable use of natural resources; sustainable competitiveness; energy efficiency and performance; the prevention and recycling of waste; resource efficiency (RE) and the circular economy (CE). The European Commission (EC) communication On Resource Efficiency Opportunities in the Building Sector (EC, 2014b) recognised the importance of design and material choice decisions in the transition towards a more resource-efficient and low carbon dioxide sector and has called for reliable indicators on: total energy and water use in buildings (including embodied and operational energy and water); material use and the associated embodied environmental impacts; C\&DW management; the recyclability, reusability and recycled content of materials; the durability and deconstruction of buildings and their material constituents (EC, 2017).

In Ireland, the national strategy, Towards a Resource Efficient Ireland (EPA, 2014), has identified RE and waste prevention as two of the key drivers to the vision of a future CE. Over the past 15 years in Ireland, a series of key legislative, policy actions and guidelines have focused on minimising waste production, reducing water use during occupation, improving energy performance and reducing GHG emissions. This has had mixed results with considerable improvements witnessed in the specification of improved energy performance in buildings focusing on the operational phase through the implementation of the Energy Performance of Buildings Directive (EU, 2010a) and subsequent revisions to the Technical Guidance Documents. Efforts to decouple waste production from construction output have been less successful as there is still a clear relationship between the two as evidenced by a 
comparison of C\&DW data with the construction production index published by the Central Statistics Office (CSO) (Table 1). Since 1995 there have been 14 national waste reports published by Ireland's Environmental Protection Agency, which show that the rising quantities of C\&DW decreased from a peak in 2007 to a low of $3 \mathrm{Mt}$ in 2011. (Note that the 2014 data are as presented in the Ireland's Environment - An Assessment 2016 (EPA, 2016) report and the 2017 data are as presented in the National Waste Statistics Summary Report 2020 (EPA, 2020).) This is reflective of the economic downturn and its effect on the construction sector during this period; however, the data for 2014 and 2017 once again show an increase in C\&DW volumes of over 56\% since 2011, which is matched by an increase in the construction production index of $74.5 \%$

A key challenge will be to decouple C\&DW production from construction output as mentioned above. Therefore, this study aims to identify opportunities to reduce waste production during the construction phase of the selected case studies along with energy and water consumption. This addresses a gap in construction-related energy research to date as it focuses on an aspect of the initial embodied energy use arising out of construction site activities (Guo et al., 2019) and builds on previous construction waste management studies (Cahill, 2007;
Gottsche and Kelly, 2018; Gottsche et al., 2016; Grimes, 2005; Kelly, 2006; Kelly and Dowd, 2014, 2015) within an RE approach - that is, the combination of energy, waste and water reduction initiatives. The use of an RE site audit tool aimed at highlighting opportunities to reduce construction-phase environmental impacts that have been commonly assumed or ignored by practitioners to date (Gustavsson et al., 2010; Iddon and Firth, 2013; Ueda et al., 2019). Waste and Resources Action Programme (Wrap) in the UK has identified $\mathrm{RE}$ as the single most effective response to addressing the risks from resource scarcity (Wrap, 2015).

\section{RE-related legislation and policy in Europe and Ireland}

The EU has adopted more than 200 pieces of environmental legislation since the 1970s, while over the past decade the sustainable use of natural resources has received increasing attention in EU policy to address environmental, climate, economic efficiency and security of supply objectives. It is a central element in the 2050 vision for Europe, as laid down in the 7 th Environment Action Programme (7th EAP) Living Well, Within the Limits of our Planet (EC, 2013). However, it was not until 2010 that RE was explicitly put on the EU policy agenda with the adoption of the Europe 2020 strategy (EC,

Table 1. C\&DW volumes compared with construction production index (Ireland 1990-2019)

\begin{tabular}{|c|c|c|c|c|}
\hline Year & Total C\&DW & $\begin{array}{c}\text { Increase/decrease \% } \\
\text { in C\&D waste }\end{array}$ & $\begin{array}{l}\text { Value of production } \\
\text { index in construction } \\
\text { (CSO data) }\end{array}$ & $\begin{array}{l}\text { Increase/decrease \% } \\
\text { in construction } \\
\text { production index: \% }\end{array}$ \\
\hline 2019 & \multicolumn{2}{|c|}{ No waste report published to date } & 172.1 & +10.8 \\
\hline 2018 & \multicolumn{2}{|c|}{ No waste report published to date } & 155.3 & +16.8 \\
\hline 2017 & 4700000 & \multirow[t]{3}{*}{+42} & 133.0 & +17.3 \\
\hline 2016 & No waste repor & & 113.4 & +13.4 \\
\hline 2015 & No waste repor & & 100.0 & +8.7 \\
\hline 2014 & 3310000 & \multirow[t]{3}{*}{$+10.2 \%$} & 92.0 & +9.4 \\
\hline 2013 & No waste repor & & 84.1 & +12.1 \\
\hline 2012 & No C\&DW data in report & & 75.0 & -1.6 \\
\hline 2011 & 3003691 & -13.3 & 76.2 & -18.8 \\
\hline 2010 & 3464683 & -32 & 93.8 & -28.9 \\
\hline 2009 & 5093666 & -62.3 & 132.0 & -37.8 \\
\hline 2008 & 13500000 & -24 & 212.4 & -26.8 \\
\hline 2007 & 17791745 & +5.8 & 290.2 & -9.2 \\
\hline 2006 & 16819904 & +13 & 319.8 & +9.9 \\
\hline 2005 & 14931486 & +123 & 290.9 & +15 \\
\hline 2004 & 11167599 & +206 & 252.8 & +19.8 \\
\hline 2003 & \multicolumn{2}{|c|}{ No C\&DW data in report } & 211.0 & +11.8 \\
\hline 2002 & \multicolumn{2}{|c|}{ No C\&DW data in report } & 188.7 & +6.8 \\
\hline 2001 & 3651411 & +35 & 176.6 & +13.3 \\
\hline 2000 & \multicolumn{2}{|c|}{ No waste report published } & 155.9 & N/A \\
\hline 1999 & \multicolumn{2}{|c|}{ No waste report published } & No data available from CSO & N/A \\
\hline 1998 & 2704958 & +78 & No data available from CSO & N/A \\
\hline 1997 & \multicolumn{2}{|c|}{ No waste report published } & No data available from CSO & N/A \\
\hline 1996 & \multicolumn{2}{|c|}{ No waste report published } & No data available from CSO & N/A \\
\hline 1995 & 1520000 & -40 & No data available from CSO & N/A \\
\hline 1990 & 2500000 & N/A & No data available from CSO & \\
\hline
\end{tabular}


2010) and its flagship initiative for a resource-efficient Europe (EC, 2011a, 2011b) that defined the political goal of 'allowing the economy to create more with less, delivering greater value with less input, using resources in a sustainable way and minimising their impacts on the environment' (EC, 2011a, 2011b). The flagship initiative set out to create a framework for policies to support the shift towards a resource-efficient and low carbon dioxide economy. The Roadmap to a Resource Efficient Europe (EC, 2011a, 2011b) of the same year proposed that buildings should be renovated and constructed with greater RE that would require policies looking at a wide range of environmental impacts across the entire life cycle (EC, 2011a, 2011b). A key challenge in this respect is to decouple environmental pressures and impacts from economic development. The 2012 Strategy for the Sustainable Competitiveness of the Construction Sector and its Enterprises (EC, 2012) reiterated that $\mathrm{RE}$ is among the main challenges that the sector faces in the period up to 2020 (EC, 2012).

Europe 2020 (EC, 2010) is the EU's growth strategy to 2020, and the aim of the strategy is to make the EU's economy a smart, sustainable and inclusive economy. The strategy aims to reduce GHG emissions by $20 \%$ compared with those in 1990 , increase the share of renewable energy in final energy consumption to $20 \%$ and achieve a $20 \%$ increase in energy efficiency. In 2014, the EC also agreed on the 2030 climate and energy policy framework for the EU setting an ambitious economy-wide domestic target of at least $40 \%$ GHG emission reduction for 2030 (EC, 2014a). The Paris Agreement 2015 (COP21) vindicated the EU's approach, when 195 countries adopted the first-ever universal, legally binding global climate deal (UN, 2015). While there are several instruments that have an impact on buildings and construction products such as the Energy Performance of Buildings Directive (EU, 2010a), the Energy Efficiency Directive (EU, 2012), the Construction Products Regulation (EU, 2011), the EU Emissions Trading System (EC, 2015c), the Industrial Emissions Directive (EU, 2010b), the Waste Framework Directives (WFDs; EU, 2008, 2018) and the Landfill Directive (EC, 1999), they focus on different resources and parts of the life cycle and for the time being they are not designed to provide an overall life-cycle approach (LCA). Therefore, one of the priority objectives of the 2013 7th EAP is to turn the EU into a resource-efficient, green and competitive low carbon dioxide economy (EC, 2013). One solution proposed to achieve this has been the concept of the CE and its application to the built environment that has gained considerable industry and policy support internationally and at the EU level over the past few years. The long-term vision of the 7th EAP is for a CE where nothing is wasted and where natural resources are managed sustainably (EC, 2013). To 'close the loop' and develop a CE the EU's circular economy package (EC, 2015a) consists of an action plan with a list of follow-up initiatives and corresponding timelines, and four new legislative proposals on waste. The $\mathrm{CE}$ is an essential contribution to the efforts of EU to develop a sustainable, low carbon dioxide, resource-efficient and competitive economy. The EU Action Plan for the Circular Economy (EC, 2015a) addresses five main areas: production (including product design and production processes); consumption (including labelling, reuse, repair, planned obsolescence and public procurement); waste management (including extended producer responsibility, recycling and harmonisation of methodologies); supporting markets for secondary raw materials and horizontal measures (including innovation, investment and monitoring). Key drivers include: the EU Action Plan for the Circular Economy (EC, 2015a) that proposes a restoratively designed economy to keep products, components and materials at their highest value at all times (EMF, 2015); the EC communication On Resource Efficiency Opportunities in the Building Sector (EC, 2014b) that calls for more resourceefficient design, planning, manufacturing and construction; the EU Construction and Demolition Waste Management Protocol (EC, 2016) that highlights the need of increasing confidence in C\&DW management processes and C\&D recycled materials; and the Guidelines for the Waste Audits before Demolition and Renovation Works of Buildings (EC, 2018).

The new WFD (EU, 2018) was approved by the EU in July 2018 and was transposed into Irish Law in July 2020. It requires EU member states to improve their waste management systems, to improve the efficiency of resource use and to ensure that waste is valued as a resource (EP, 2018). A large proportion of Ireland's RE policy legislation is based on EU initiatives and directives and these directives are then transposed into Irish Law through legislation and policies of Ireland. The Irish government has implemented a number of policy and legislative documents dating back to 1996 with the implementation of the Waste Management Act (WMA) (ISB, 1996). The main objectives of the WMA were to improve performance of prevention and recovery of waste and to set out a regulatory framework in response to EU and national requirements (ISB, 1996). The 1996 WMA was subsequently amended by the WMA 2001 (ISB, 2001) and the Protection of the Environment Act 2003 (ISB, 2003). These Acts are the legislative basis for all waste management (WM) issues in Ireland. The WFD 2008 (EU, 2008) was entered into Irish Law in March 2011 and sets out the concepts and definitions relating to WM, such as the definitions of waste, recycling and recovery. It also explains when waste ceases to be waste and becomes a secondary raw material (so-called end-of-waste criteria), and how to distinguish between waste and by-products (EU, 2008). Also articles 28(1) and 29(1) of the WFD emphasise that waste management plans and waste prevention should be established in accordance with the waste hierarchy (EU, 2008). Ireland's RE strategy was published in 2014 in the Towards a Resource Efficient Ireland: A National Strategy to 
2020 document (EPA, 2014). While the document does not contain specific targets for the construction sector, the overarching objective is to implement EU and national policy on $\mathrm{RE}$ to break the link between economic growth and environmental impact. More specifically, it aims to reduce wasteful consumption of material, water and energy resources by changing behaviours, and enhance competitiveness and reduce business costs through the implementation of RE and the CE (EPA, 2014). There is currently no specific construction industry RE legislation in place in Ireland as RE is distributed among the other sectors' policies such as environment, energy and waste. The government's Construction 2020: Strategy for a Renewed Construction Sector (DHPLG, 2014) provides the basis for rebuilding a sustainable (in the economic sense) construction sector that has the capacity to build the houses and infrastructure that a society needs, and making its full contribution to economic recovery (EC, 2015b). The document does not mention the sustainable management of C\&DW. The focus now must be on the actual WM and minimisation if these legislative improvements are to be maintained and national targets for C\&DW recovery are to be achieved. In order to achieve the targets, set out in the policy and legislation, a radical change in attitudes, design considerations and on-site $\mathrm{WM}$ is needed.

Waste prevention, energy management and water management within the construction sector will play a central role in enhancing $\mathrm{RE}$ and creating a $\mathrm{CE}$ that enables society to maximise the economic return on scarce resources (EC, 2020). Europe and Ireland can gain many social and economic benefits from treating waste as a resource with the EC estimating that the implementation of CE models will create 580000 jobs in the EU alone and save EU companies $€ 600$ billion (EP, 2018). The CE is expected to boost the EU's competitiveness by protecting businesses against scarcity of resources and volatile prices, helping to create new jobs and business opportunities and innovative, more efficient ways of producing and consuming. At the same time, it will save energy and help avoid the irreversible damages caused by using resources at a rate that exceeds the Earth's capacity to renew them in terms of climate and biodiversity, air, soil and water pollution (EC, 2020).

\section{Literature review}

Over the last 20 years, the concept of sustainability has been growing in importance and it has currently become the basis of most socio-economic activities and developments in the built environment (Edum-Fotwe and Price, 2009; Kelly et al., 2019). However, the implementation of RE strategies to reduce GHG emissions and improve competitiveness has not yet been sufficiently tested by research. Collaborative research is needed to assess the merits of different RE strategies (Bleischwitz, 2011; EPA, 2019).
The construction industry is aware that it has an important role to play in minimising waste production (Gálvez-Martos et al., 2018; Osmani, 2012) because materials and resources are vital in terms of supporting the industry (Kabirifar et al., 2020; Knoeri et al., 2011). The trend of previous peer-reviewed C\&DW research to date has focused on general C\&DW management (Tam, 2008), recycling, waste reduction techniques (Poon, 2007), generation, reuse and human factors through case studies, surveys, reviews and experiments (Yuan and Shen, 2011) and the identification of best practice for the management of C\&DW (Gálvez-Martos et al., 2018). Additional studies have also focused on modern approaches to waste minimisation such as the use of building information modelling (BIM) (Liu et al., 2015; Lu et al., 2017; Xu et al., 2019). Despite this level of research, several authors have noted that the practical implementation of C\&DW management strategies has been far from effective (Ajayi et al., 2015, 2016; Gálvez-Martos et al., 2018; Kofoworola and Gheewala, 2009; Lingard et al., 2000; Osmani et al., 2006; Tam, 2008; Yuan and Shen, 2011). At a project-level scale, Cheshire (2016), the Ellen MacArthur Foundation (EMF, 2015) and Wrap in the UK (Wrap, 2015) have provided a series of case studies that demonstrate how RE and circularity strategies can be embedded into the construction process by using low embodied, low toxicity, recycled and resource-efficient materials and components; improving energy performance; designing for deconstruction; designing out waste and using performancerelated services - that is, fixtures and fittings. While a large volume of research has been carried out on the management and reduction of C\&DW there is still a lack of research on the actual implementation of waste strategies in construction projects during the construction phase. To identify waste reduction opportunities (and RE opportunities), it is essential that the different phases of a building's life cycle are explored that includes a considerable amount of waste produced and the energy and water used during the construction process. When projected on to a building's life cycle, the research therefore concentrated on several life cycle phases including the construction, fit-out and retrofit phases.

Literature about energy reduction initiatives in other areas such as the manufacturing industry is extensive (Blackhurst et al., 2011; Cheng et al., 2020; Hallinan et al., 2012; Mujtaba et al., 2012; Woroniak and Piotrowska, 2014) but the literature in relation to energy usage on construction sites, during the construction phase, is lacking (Acquaye and Duffy, 2010; Davies et al., 2014, 2015; Guo et al., 2019; Hong et al., 2015). With regards to energy, to date, all national estimates have referred to operational energy, for example energy usage in the residential sector (SEAI, 2015), with some studies focusing on the embodied energy used during the pre-construction phases only (Acquaye and Duffy, 2010; Fenner et al., 2020; Goggins et al., 2010; Hong et al., 2016). Previous research has reflected 
the legislative and policy approach to energy efficiency by focusing primarily on design and operational energy opportunities with less of an emphasis on embodied energy, particularly related to on-site construction activities (Bilec et al., 2006; Davies et al., 2015; Guo et al., 2019). Energy use during the material, transportation and construction phases up to project practical completion is known as initial embodied energy. Previous research has focused on sections of this initial embodied energy, such as Dixit et al. (2015) who analysed the embodied energy of construction materials, Salcido et al. (2016) who compared the embodied energy of alternate materials for a construction project and Davies et al. (2015) who assessed the initial embodied energy associated with material extraction, transportation and construction phases. However, although it is important to consider this overall LCA in initial embodied energy it is also important to analyse the construction phase as a standalone element of the project life cycle, as the overall initial embodied impact has been deemed to be greater than the operational impact at the end of a building's 25-year lifespan (Davies et al., 2015). The construction phase does offer more readily available 'live' data in the form of fuel receipts (petrol and diesel), metered energy use (gas and electricity) and plant/material registers that can address the perceived lack of quantifiable construction-phase embodied energy benchmarks (Bilec et al., 2006; Davies et al., 2013, 2014; Li et al., 2010; Paganin et al., 2017). This study focused on the enabling works, assembly processes and the installation work during the construction phase of four case study buildings to evaluate the impact of selected energy, waste and water reduction measures in terms of cost, energy savings (in $\mathrm{kWh}$ ) and carbon dioxide $\left(\mathrm{CO}_{2}\right)$ emissions.

Water consumed directly by the construction industry has largely not been considered (Choudhuri, 2015; McCormack et al., 2007). While water used to operate buildings is a significant component of worldwide water consumption, this is not the only form of water consumed throughout a building's life cycle (Akadiri et al., 2012; Choudhuri, 2015). Water is also consumed in the extraction, production, manufacturing and delivery of materials and products to site, and the actual onsite construction process. The research carried out on water usage in the construction sector to date has largely focused on water quality monitoring during civil engineering and construction projects (Amado, 2013; Belayutham et al., 2016a; Belayutham et al., 2016b; Cocchiglia et al., 2012; Houser and Pruess, 2009; Ooshaksaraie, 2011), while the impact of construction and civil engineering projects on water bodies has also been assessed (Raposo et al., 2010; Rybka et al., 2016). Stephan and Crawford (2014) found that studies typically consider only operational water that excludes the embodied water of a construction project. Additional research has also focused on elements of the embodied water in buildings with McCormack et al. (2007), Han et al. (2016) and Meng et al.
(2016) assessing the water embodied in building materials while Crawford and Pullen (2011) and Stephan and Crawford (2014) focused on an analysis of the life cycle of water in residential buildings. However, this embodied water does not feature significantly within the literature. Therefore, this study will also address this gap in the research by analysing the usage of water on construction sites and investigate the methods that can be used to reduce this usage.

Research has previously been undertaken on the various individual facets of RE as detailed above - that is, waste, energy and water; however, this previous research has focused on individual strands of RE whereas this study uses a more holistic approach to include these strands in one research project. Therefore, this study will address the research gap that exists for analysing the implementation of RE measures during construction and investigate the impact of reduction measures that can be undertaken during the construction phase of a project. This study therefore represents the first comprehensive attempt to provide quantitative guidance regarding the implementation of RE strategies within the Irish construction industry.

\section{Methodology}

This study employed a case study methodological approach in collaboration with a small-to-medium enterprise building contractor based in the West of Ireland. The study consisted of four case study projects that were undertaken over a 2-year period; these four case study projects ranged in value from $€ 95000$ to $€ 1.6$ million and ranged from 199.5 to $401.3 \mathrm{~m}^{2}$ in floor area. During the research, 85 site visits were carried out along with the completion of $69 \mathrm{RE}$ audits. Details of the case studies are presented in Table 2.

The contractor provided a suitable sample due to its fundamental role during the construction phase (Davies et al., 2014) and its willingness to examine current on-site practices to facilitate pragmatic action research (AR). This involved active participation by the researcher during the construction phase to explore the setting with a view to advancing understanding of the research area (Cousin, 2005; Fellows and Liu, 2012; Taggart et al., 2014) that in this case was RE on site. The following series of activities were undertaken to identify 'actionable' interventions (Altrichter et al., 2002; Baskerville, 1999; Brownlee et al., 2019; Coughlan and Coughlan, 2002; Huxham and Vangen, 2003): site visits; on-site observations; site meetings with management; informal dialogue with site personnel; auditing and benchmarking energy and water use and waste production. This approach was framed by the cyclical model proposed by Susman and Evered (1978), who outlined the following key stages: diagnosing the issue or problem; developing an action plan to address the problem or improve 
Table 2. Summary of case study projects

\begin{tabular}{|c|c|c|c|c|}
\hline Case study number and name & Project type & Floor area: $\mathrm{m}^{2}$ & Value & Project length: months \\
\hline $\begin{array}{c}\text { Case study } 1 \\
\text { Block M }\end{array}$ & Demolition and landscaping & 199.5 & $€ 95000$ & 1 \\
\hline $\begin{array}{c}\text { Case study } 2 \\
\text { CF unit }\end{array}$ & New build healthcare & 223.8 & $€ 590000$ & 9 \\
\hline $\begin{array}{l}\text { Case study } 3 \\
\text { Podiatry unit }\end{array}$ & New build healthcare & 401.3 & $€ 1600000$ & 9 \\
\hline $\begin{array}{l}\text { Case study } 4 \\
\text { HDU }\end{array}$ & Demolition and fit out & 212 & $€ 765000$ & 3.5 \\
\hline
\end{tabular}

the situation; implementation of the plan; evaluating the impact and specifying learning from this process (Figure 1).

The cyclical nature of the AR process provided the flexibility required to accommodate the construction project setting for the research and supported the necessity to divide the project into individual case study projects, where each complete cycle would inform the implementation of RE strategies in subsequent projects. This reflective process of progressive problem solving was carried out using a 'Lessons Learned' report that was presented to the case study contractor following the completion of each case study. This also enabled the research to systematically build on the problem solution and move towards a more holistic understanding, a key characteristic of AR (Coghlan and Brannick, 2005). This required the establishment of a client-system infrastructure (Chein, 1948; Susman and Evered, 1978) to facilitate a close collaborative working environment that encouraged deep participant involvement (Neilsen and Neilsen, 2006).

Several existing auditing tools were used during the project phases including the Sustainable Energy Authority of Ireland (SEAI) Energy Tracker tool; SEAI Register of Opportunities tool; SEAI Significant Energy Users tool (all available from the

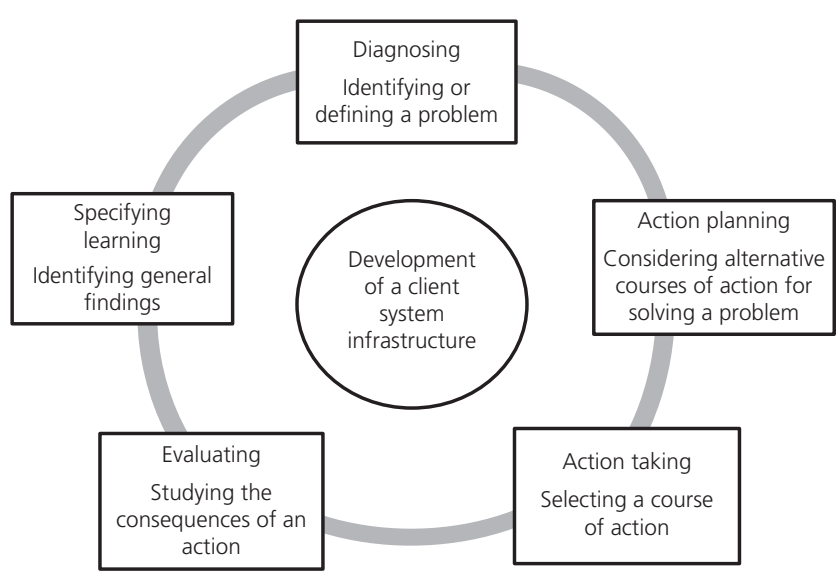

Figure 1. AR cycle (source: Susman and Evered (1978))
SEAI website (SEAI, 2020)) and the Galway Mayo Institute of Technology Construction and Demolition Waste Audit book (not currently publicly available). The use of these tools informed the development of an RE auditing tool that was used on a weekly basis to benchmark RE practices on the selected case studies and allowed for the tracking of energy, waste and water usage data. This tool, in turn, informed the preparation of the RE plans that were implemented in the site. The initiatives were carefully monitored and evaluated to determine their effectiveness; identify any limitations or barriers and produce a set of key performance indicators (KPIs) for RE.

\section{Results and discussion}

This study sets out to explore the use of quick-win RE interventions during the construction phase and identified a series of RE initiatives that, when implemented, reduced the environmental impact of on-site activities and making significant cost savings. In addition, recommendations were made on how to improve RE practice on site that suggested further savings. It was clear from the analysis of RE on the case studies that opportunities exist to move the focus higher up the waste hierarchy towards reuse and prevention and that energy management can also be significantly improved. To address this, the following waste prevention, energy and water reduction practices were implemented: materials' optimisation; waste segregation and benchmarking; appropriate materials' management and logistics; use of minimal packaging; facilitating material take-back schemes, reuse of materials on site, night-time energy management, lighting controls and the installation of a water tap and tool-washing area. Results suggest that the case study contractor was open to most of these initiatives with the largest cost savings for the main contractor made in relation to waste segregation, reuse of materials, material and packaging take-back schemes and night-time energy management. A total of $74 \mathrm{RE}$ initiatives were implemented on the four case study sites that included 49 waste management initiatives (Table 3), 11 energy management initiatives (Table 4) and 14 water management initiatives (Table 5) as shown in Tables 3-5.

The total cost savings, energy savings (kWh), waste reduction estimates ( $\mathrm{t}$ ), diversion from landfill levels and the carbon 
Table 3. Waste management initiatives implemented in the case study projects

\begin{tabular}{|c|c|c|c|c|}
\hline Waste management initiatives implemented & $\begin{array}{l}\text { Block } \\
\text { M }\end{array}$ & $\begin{array}{l}\text { CF } \\
\text { unit }\end{array}$ & Podiatry & HDU \\
\hline Identification of waste causes, quantities and composition throughout the project & $\checkmark$ & $\checkmark$ & $\checkmark$ & $\checkmark$ \\
\hline RE audits incorporating waste management on site & $\checkmark$ & $\checkmark$ & $\checkmark$ & $\checkmark$ \\
\hline Pre-demolition audit to identify recycling and reuse opportunities within the existing structure & $\checkmark$ & N/A & $\times$ & $\times$ \\
\hline Source segregation of waste produced on site with correct skip signage in place at all times & $\checkmark$ & $\times$ & $\checkmark$ & $\times$ \\
\hline Use of a segregated timber waste skip & $\checkmark$ & $\times$ & $\checkmark$ & $\times$ \\
\hline Use of a segregated metal waste skip & $\checkmark$ & $\times$ & $\times$ & $\times$ \\
\hline Use of a segregated bin for office and canteen waste & N/A & $\times$ & $\checkmark$ & $\checkmark$ \\
\hline Timber pallets segregated on site and returned to suppliers through a take-back scheme & $\times$ & $\checkmark$ & $\checkmark$ & $\checkmark$ \\
\hline Timber cable drums segregated on site and returned to suppliers through a take-back scheme & $\mathrm{N} / \mathrm{A}$ & $\checkmark$ & $\checkmark$ & $\checkmark$ \\
\hline $\begin{array}{l}\text { Removal of landscaping/building materials prior to construction works that were incorporated into the } \\
\text { final design }\end{array}$ & $\times$ & $\checkmark$ & $\checkmark$ & $\checkmark$ \\
\hline Sand and stone delivered in canvas bags to site to reduce material wastage through poor storage & $\mathrm{N} / \mathrm{A}$ & $\checkmark$ & $\checkmark$ & $\checkmark$ \\
\hline Hoarding and hoarding posts removed and stored for reuse in future projects & N/A & $\sqrt{ }$ & $\checkmark$ & $\checkmark$ \\
\hline $\begin{array}{l}\text { Use of material optimisation when ordering materials - for example, metal stud wall system, } \\
\text { plasterboard and ceiling tiles }\end{array}$ & $\mathrm{N} / \mathrm{A}$ & $\checkmark$ & $\checkmark$ & $\checkmark$ \\
\hline Setting up of central cutting and storage areas for plasterboard and carpentry trades & N/A & $\sqrt{ }$ & $\checkmark$ & $\checkmark$ \\
\hline Selection of a waste management contractor with a high diversion from landfill rate & $\checkmark$ & $\checkmark$ & $\checkmark$ & $\checkmark$ \\
\hline Festoon lighting system removed correctly and stored for use in future projects & $\mathrm{N} / \mathrm{A}$ & $\times$ & $\checkmark$ & $\checkmark$ \\
\hline Timber shuttering kept for reuse in subsequent projects & N/A & $\times$ & $\checkmark$ & $\times$ \\
\hline Minimal use of 'floor guard' protection materials when nearing project completion & N/A & $\times$ & $\checkmark$ & $\checkmark$ \\
\hline Specification of off-site-manufactured components such as sink splash backs, doors and door frames & N/A & $\checkmark$ & $\checkmark$ & $\checkmark$ \\
\hline
\end{tabular}

Table 4. Energy management initiatives implemented in the case study projects

$\begin{array}{lllll}\text { Energy management initiatives implemented } & \text { Block M } & \text { CF unit } & \text { Podiatry } & \text { HDU } \\ \text { Identification of energy usage and causes of energy wastage throughout the project } & \times & \times & \times & \checkmark \\ \text { RE audits incorporating energy management on site } & \checkmark & \checkmark & \checkmark & \checkmark \\ \text { Site lighting switched off at the close of each working day to reduce night-time energy use } & \text { N/A } & \checkmark & \checkmark \\ \text { Transformer boxes on site switched off at night-time, weekends and holidays } & \text { N/A } & \times & \checkmark & \checkmark \\ \text { Temporary lighting switched off on site during daylight hours } & \text { N/A } & \times & \checkmark \\ \text { External security lighting fitted with photocell technology } & \text { N/A } & \times & \times\end{array}$

Table 5. Water management initiatives implemented in the case study projects

\begin{tabular}{lccc} 
Water management initiatives implemented & Block M & CF unit & HDU \\
\hline Identification of causes of water wastage throughout the project & $\checkmark$ & $\checkmark$ & $\checkmark$ \\
RE audits incorporating water management on site & N/A & $\checkmark$ \\
Installation of a tap system to minimise water wastage & N/A & $\checkmark$ \\
Use of a tool-washing bin system for wet trades & $\checkmark$
\end{tabular}

dioxide savings $(\mathrm{t})$ are outlined in Table 6 for the four case study projects.

The total cost savings arising out of implemented waste management initiatives were estimated to be $€ 14567.70$ over the four case studies, which represented $0.48 \%$ of the total project value ( $€ 3050032$ ) and $15.9 \%$ of a theoretical profit margin of $3 \%$ (€91 500.96). As well as reducing costs, a wellmanaged approach provided quantifiable evidence that can be used to demonstrate cost savings and a responsible approach to resource use. The implemented measures reduced the energy usage in the case study projects by a total of $11373.09 \mathrm{kWh}$, reduced the waste production by $176.751 \mathrm{t}$ and reduced carbon dioxide emissions by $34.941 \mathrm{t}$. The implementation of RE initiatives was achievable and cost savings were made in many areas of RE. Addressing RE shortcomings provided the case study contractor with additional profit, reduced carbon dioxide emissions in the projects and had the added benefit of helping the contractor to become more competitive within the industry (reduced overheads). The financial position of the 
Table 6. Implemented RE measures in site - results

\begin{tabular}{|c|c|c|c|c|}
\hline KPI & Block M & CF unit & Podiatry & HDU \\
\hline Project value: $€$ & 95000 & 590000 & 1600000 & 765032 \\
\hline Cost savings: $€$ & 680.36 & 1961.16 & 8834.61 & 3091.57 \\
\hline Savings on project value: \% & 0.72 & 0.33 & 0.55 & 0.40 \\
\hline Saving per $\mathrm{m}^{2}$ floor area: $€$ & N/A & 8.76 & 22.01 & 14.58 \\
\hline Energy savings: kWh & N/A & 1908.06 & 6028.59 & 3436.44 \\
\hline Waste reduction: $t$ & N/A & 4.69 & 164.03 & 8.031 \\
\hline Diversion from landfill: $t$ & 99.7 & 90 & 90 & 90 \\
\hline Carbon dioxide emission reduction ( $\mathrm{t}$ ) from energy savings & N/A & 1.215 & 3.84 & 1.189 \\
\hline Carbon dioxide emission reduction (t) from waste reduction & N/A & 3.067 & 6.449 & 4.987 \\
\hline Carbon dioxide emission reduction ( $\mathrm{t}$ ) from waste diversion from landfill & 1.48 & 1.648 & 6.191 & 4.925 \\
\hline
\end{tabular}

construction industry in Ireland is not what it used to be, with many contractors working to low-profit margins (SCSI/PwC, 2019) and thus all the RE incentives proposed were balanced against additional implementation costs. All the initiatives implemented were quick-win options with low to no implementation costs. This is a similar finding to a Wrap study in 2015 which found that a structured approach to resource management planning will deliver significant reductions in resource use, often with little or no capital investment (Wrap, 2015).

The evaluation of RE initiatives in terms of profit margins, energy savings $(\mathrm{kWh})$ and carbon dioxide emission reduction differs from previous studies (Cole, 1999; Davies et al., 2013, 2014, 2015; Guo et al., 2019; Gustavsson et al., 2010; Hong et al., 2015; Ramesh et al., 2010) that attempted to benchmark construction-phase energy use to identify its contribution to the overall building life cycle energy use. For the purposes of this study and to encourage further co-operation and collaboration of industry, it was vital to clearly demonstrate the financial implications of implemented RE initiatives on site. This pragmatic approach aimed at influencing change by providing situated knowledge that would enable and empower project participants to exploit opportunities in RE improvement. Furthermore, RE fits well within wider business improvement initiatives, linking with the introduction of BIM, supply chain management and lean construction. By re-examining where resources are wasted, it is often possible to identify better ways of working that deliver cost, environmental, quality and other project benefits.

Although it is recognised that these results cannot be extrapolated across the construction sector due to differences in on-site management practices, data collection and reporting structures (Davies et al., 2013), it is important to highlight that the measures of RE improvement that were implemented on site are easily repeatable across the sector. This actionable knowledge is highly relevant to the Irish construction sector in the current economic environment, including the impact of Covid-19 on the sector, as it provides an opportunity to increase profit margins while also reducing negative environmental impacts.

\section{Conclusions and recommendations}

The implementation of RE measures in the four selected case studies produced cost savings of $€ 14567.70$ representing $0.48 \%$ of the total project value (€3 050032$)$ and $15.9 \%$ of an estimated overall profit margin of $3 \%(€ 91500.96)$. The total energy savings were estimated to be $11373.09 \mathrm{kWh}$ by switching off lighting, reducing night-time energy use and installing photocells. In addition, it was estimated that $176.751 \mathrm{t}$ of materials were prevented from being placed in site skips through waste segregation, material optimisation measures, supplier take-back schemes, reuse of materials and appropriate materials management on site. The water management initiatives included the installation of a tap system and the use of tool-washing systems on site. The total reduction in carbon dioxide emissions from the implemented measures was $52.263 \mathrm{t}$, measured using the SEAI carbon calculator tools (SEAI, 2020), the Wrap Carbon Calculator for C\&DW and the Wrap Water Monitoring Tool (both available from the Wrap website (Wrap, 2020)). The detailed review of RE practices in the four selected case studies has highlighted the need for further research in the following areas.

- Auditing should continue on other case studies to identify current best practice and identify opportunities to improve RE performance during the construction phase. This will enable the development of a set of industry KPIs that can be used by organisations when they want to benchmark their on-site performance.

- The case studies outlined herein along with other identified case studies should inform the development of an industry toolkit containing practical, research-informed and evidence-based factsheets for industry stakeholders involved in the construction process.

- Further research is required to explore the concept of RE using an LCA - that is, from initial design to operation and final end-use. This fits within the CE model where greater engagement at all stages in the supply chain would 
enable the identification of material loop opportunities considering embodied elements (energy, carbon, waste and water), as well as operational and final end-use elements.

- Waste prevention and the development of supply chain material loops should be embedded in an overall RE design approach to provide a holistic template that will produce low (embodied and operational) energy buildings that produce little or no waste and use water efficiently through all stages in their life cycle.

\section{Acknowledgements}

This study was funded by the Environmental Protection Agency (EPA) Ireland under the STRIVE programme. The assistance of Paul Carey and the staff of Carey Building Contractors is also acknowledged.

\section{REFERENCES}

Acquaye AA and Duffy AP (2010) Input-output analysis of Irish construction sector greenhouse gas emissions. Building and Environment 45(3): 784-791.

Ajayi SO, Oyedele LO, Bilal M et al. (2015) Waste effectiveness of the construction industry: understanding the impediments and requisites for improvements. Resources, Conservation and Recycling 102: $101-112$.

Ajayi SO, Oyedele LO, Bilal M et al. (2016) Reducing waste to landfill: a need for cultural change in the UK construction industry. Journal of Building Engineering 5: 185-193.

Akadiri PO, Chinyio EA and Olomolaiye PO (2012) Design of a sustainable building: a conceptual framework for implementing sustainability in the building sector. Buildings 2(2): 126-152.

Altrichter H, Kimis S and McTaggart R (2002) The concept of action research. The Learning Organisation 9(3): 125-131.

Amado MP (2013) Sustainable construction: water use in residential buildings in Portugal. International Journal of Sustainable Construction Engineering Technology 4(2): 14-22.

Baskerville R (1999) Investigating information systems with action research. Communications of the Association of Information Systems 2(19): 7-17.

Belayutham S, Gonzále VA and Yiu TW (2016a) The dynamics of proximal and distal factors in construction site water pollution. Journal of Cleaner Production 113: 54-65.

Belayutham S, González VA and Yiu TK (2016b) A cleaner production-pollution prevention-based framework for construction site induced water pollution. Journal of Cleaner Production 135: 1363-1378.

Bilec M, Ries R, Matthews HS and Sharrard AL (2006) Example of a hybrid life-cycle assessment of construction processes. Journal of Infrastructure Systems 12(4): 207-215.

Blackhurst M, Azevedo IL, Matthews HS and Hendrickson CT (2011) Designing building energy efficiency programs for greenhouse gas reductions. Energy Policy 39(9): 5269-5279.

Bleischwitz R (2011) Resource efficiency - five governance challenges toward a green economy. Journal of Industrial Ecology 15(5): 644-646.

Brownlee SA, Whitson PJ and Ibrahim AM (2019) Measuring and improving the design quality of operating rooms. Surgical Infections 20(2): 102-106.
Cahill O (2007) An Analysis of the use of Photogrammetric Sorting to Audit Construction and Demolition Waste Production on Site. MSc (Research) thesis, Department of Building and Civil Engineering, Galway-Mayo Institute of Technology.

Chein I (1948) Behaviour theory and the behaviour of attitudes. Psychological Review 55(3): 175-188.

Cheng M, Shao Z, Gao F et al. (2020) The effect of research and development on the energy conservation potential of China's manufacturing industry: the case of east region. Journal of Cleaner Production 258: 120558.

Cheshire D (2016) Building Revolutions: Applying the Circular Economy to the Built Environment. RIBA Publishing, London, UK. See https://bit.ly/32v3LUC (accessed 25/08/2020).

Choudhuri IR (2015) Assessment of embodied water of construction: case study of a four-star rated hotel in New Delhi. India. International Journal of Emerging Engineering Research and Technology 3(8): 195-199.

Cocchiglia L, Kelly-Quinn M, Bruen M, O'Sullivan J and Purcell P (2012) Water quality monitoring during the construction of the M3 motorway in Ireland. Water and Environment Journal 26(2): 175-183.

Coghlan D and Brannick T (2005) Doing Action Research in Your own Organization, 2nd edn. Sage Publications, London, UK.

Cole R (1999) Energy and greenhouse gas emissions associated with the construction of alternative structural systems. Building and Environment 34(3): 335-348.

Coughlan P and Coghlan D (2002) Action research for operations management. International Journal of Operations and Production Management 22(2): 220-240.

Cousin G (2005) Case study research. Journal of Geography in Higher Education 29(3): 421-427.

Crawford R and Pullen S (2011) Life cycle water analysis of a residential building and its occupants. Building Research and Information 39(6): 589-602.

Davies PJ, Emmitt S and Firth SK (2013) On-site energy management challenges and opportunities: a contractor's perspective. Building Research and Information 41(4): 450-468.

Davies PJ, Emmitt S and Firth SK (2014) Challenges for capturing and assessing initial embodied energy: a contractor's perspective. Construction Management and Economics 32(3): 290-308.

Davies PJ, Emmitt S and Firth SK (2015) Delivering improved initial embodied energy efficiency during construction. Sustainable Cities and Society 14: 267-279.

DHPLG (Department of Housing, Planning and Local Government) (2014) Construction 2020: Strategy for a Renewed Construction Sector. Government Publications, Dublin, Ireland. See https://bit.ly/ 34wdPiy (accessed 24/08/2020).

Dixit MK, Culp CH and Fernandez-Solis JL (2015) Embodied energy of construction materials: integrating human and capital energy into an IO-based hybrid model. Environmental Science and Technology 49(3): 1936-1945.

EC (European Community) (1999) Council Directive 1999/31/EC of 26 April 1999 on the Landfill of Waste. Official Journal of the European Communities L182/1.

EC (European Commission) (2010) Europe 2020: a European Strategy for Smart, Sustainable and Inclusive Growth. European Commission, Brussels, Belgium. See https://bit.ly/31omDoX (accessed 24/08/2020).

EC (2011a) A Resource-Efficient Europe - Flagship Initiative under the Europe 2020 Strategy. European Commission, Brussels, Belgium. See https://bit.ly/2Er6Lc6 (accessed 24/08/2020). 
EC (2011b) Roadmap to a Resource Efficient Europe. European Commission, Brussels, Belgium. See https://bit.ly/3lgsT9Q (accessed 24/08/2020).

EC (2012) Strategy for the Sustainable Competitiveness of the Construction Sector and its Enterprises. European Commission, Brussels, Belgium. See https://bit.ly/3ja4KQw (accessed 24/08/2020)

EC (2013) Living Well, Within the Limits of our Planet: 7th EAPThe New General Union Environment Action Programme to 2020 Publications Office of the European Union, Luxembourg. See https://ec.europa.eu/environment/pubs/pdf/factsheets/7eap/en.pdf (accessed 21/08/2020)

EC (2014a) A Policy Framework for Climate and Energy in the Period from 2020 to 2030. European Commission, Brussels, Belgium. See https://bit.ly/34svbgj (accessed 24/08/2020).

EC (2014b) On Resource Efficiency Opportunities in the Building Sector. European Commission, Brussels, Belgium. See https://ec.europa. eu/environment/eussd/pdf/SustainableBuildingsCommunication.pdf (accessed 25/08/2020).

EC (2015a) Closing the Loop - An EU Action Plan for the Circular Economy. European Commission, Brussels, Belgium. See https://bit.ly/3hrsCP5 (accessed 24/08/2020).

EC (2015b) Construction and Demolition Waste Management in Ireland. Deloitte, Belfast, UK. See https://bit.ly/31fgE5y (accessed 21/08/2020)

EC (2015c) EU Emissions Trading System (EU ETS). European Commission, Brussels, Belgium. See https:/lec.europa.eu/clima/ sites/clima/files/docs/ets_handbook_en.pdf (accessed 24/08/2020).

EC (2016) EU Construction and Demolition Waste Management Protocol. European Commission, Brussels, Belgium. See https://bit. ly/31eDhHp (accessed 21/08/2020).

EC (2017) Level(s) - A Common EU Framework of Core Sustainability Indicators for Office and Residential Buildings. Publications Office of the European Union, Luxembourg. See https://bit.ly/3fQAbxr (accessed 13/08/2020).

EC (2018) Guidelines for the Waste Audits before Demolition and Renovation Works of Buildings. European Commission, Brussels, Belgium. See https://bit.ly/3gm8vAC (accessed 21/08/2020).

EC (2020) A New Circular Economy Action Plan for a Cleaner and more Competitive Europe. European Commission, Brussels, Belgium. See https://bit.ly/2PMelk3 (accessed 13/08/2020).

Edum-Fotwe FT and Price ADF (2009) A social ontology for appraising sustainability of construction projects and developments. International Journal of Project Management 27(4): 313-322.

EMF (Ellen MacArthur Foundation) (2015) Towards a Circular Economy: Business Rationale for an Accelerated Transition. Ellen MacArthur Foundation, Isle of Wight, UK. See https://bit.ly/316Q6LO (accessed 21/08/2020)

EP (European Parliament) (2018) Circular Economy: Definition, Importance and Benefits. European Parliament, Brussels, Belgium. See https://bit.ly/30XOlbX (accessed 13/08/2020).

EPA (Environmental Protection Agency) (2014) Towards a Resource Efficient Ireland: A National Strategy to 2020. Environmental Protection Agency, Wexford, Ireland. See https://bit.ly/33VaaKU (accessed 13/08/2020)

EPA (2016) Ireland's Environment - An Assessment 2016. Environmental Protection Agency, Wexford, Ireland. See http://www.epa.ie/pubs/reports/indicators/SoE_Report_2016.pdf (accessed 13/08/2020).

EPA (2019) Resource Efficiency in Priority Irish Business Sectors. Environmental Protection Agency, Wexford, Ireland. See http://www.epa.ie/pubs/reports/research/waste/Research_Report_ 271.pdf (accessed 24/08/2020)
EPA (2020) National Waste Statistics Summary Report 2020. Environmental Protection Agency, Wexford, Ireland. See https://bit.ly/30T70ph (accessed 13/08/2020).

EU (European Union) (2008) Directive 2008/98/EC of the European Parliament and of the Council on waste and repealing certain Directives. Official Journal of the European Union L312/3. See https://eur-lex.europa.eu/legal-content/EN/TXT/PDF/?uri= CELEX:32008L0098\&from=EN (accessed 21/08/2020).

EU (2010a) Directive 2010/31/EU of the European Parliament and of the Council of 19 May 2010 on the Energy Performance of Buildings. Official Journal of the European Union L153/13. See https://bit.ly/3hpzInb (accessed 24/08/2020).

EU (2010b) Directive 2010/75/EU of the European Parliament and of the Council of 24 November 2010 on Industrial Emissions (Integrated Pollution Prevention and Control). Official Journal of the European Union L334/17. See https://bit.ly/2Eccq6d (accessed 24/08/2020).

EU (2011) Regulation (EU) No. 305/2011 of the European Parliament and of the Council of 9 March 2011 Laying Down Harmonised Conditions for the Marketing of Construction Products and Repealing Council Directive 89/106/EEC. Official Journal of the European Union L88/5. See https://bit.ly/3llioCz (accessed 24/08/2020).

EU (2012) Directive 2012/27/EU of the European Parliament and of the Council of 25 October 2012 on Energy Efficiency, Amending Directives 2009/125/EC and 2010/30/EU and Repealing Directives 2004/8/EC and 2006/32/EC. Official Journal of the European Union L315/1. See https://bit.ly/34sd8qx (accessed 24/08/2020).

EU (2018) Directive (EU) 2018/851 of the European Parliament and of the Council of 20 May 2018 amending Directive 2008/98/EC on waste. Official Journal of the European Union L150/109. See https://eur-lex.europa.eu/legal-content/EN/TXT/PDF/?uri= CELEX:32018L0851\&from=EN (accessed 21/08/2020).

Fellows R and Liu A (2012) Research Methods in Construction, 3rd edn. Blackwell Publishing, London, UK.

Fenner AE, Kibert CJ, Li J et al. (2020) Embodied, operation, and commuting emissions: a case study comparing the carbon hotspots of an educational building. Journal of Cleaner Production 268, N.PAG.

Gálvez-Martos JL, Styles D, Schoenberger H and Zeschmar-Lahl B (2018) Construction and Demolition Waste Best Management Practice in Europe. Resources, Conservation and Recycling 136: 166-178.

Goggins J, Keane T and Kelly A (2010) The assessment of embodied energy in typical reinforced concrete building structures in Ireland. Energy and Buildings 42(5): 735-744.

Gottsche J and Kelly M (2018) Assessing the impact of construction waste reduction on selected projects in Ireland. Proceedings of the Institution of Civil Engineers - Waste and Resource Management 171(3): 71-81, https://doi.org/10.1680/jwarm.17.00034.

Gottsche J, Kelly M and Taggart M (2016) Assessing the impact of energy management initiatives on the energy usage during the construction phase of an educational building project in Ireland. Construction Management and Economics 34(1): 46-60.

Grimes D (2005) The Assessment of Construction and Demolition Waste Arising on Selected Case Study Construction Projects in the Galway Region. MSc (Research) thesis, Department of Building and Civil Engineering, Galway-Mayo Institute of Technology, Galway, Ireland.

Guo S Z, Hu Y, Hong J, Wu X and Tang M (2019) Embodied energy use in the global construction industry. Applied Energy 256: 113838.

Gustavsson L, Joelsson A and Sathre R (2010) Life cycle primary energy use and carbon emission of an eight-storey wood-framed apartment building. Energy and Buildings 42(2): 230-242. 
Hallinan K, Enns H, Ritchey S et al. (2012) Energy information augmented community-based energy reduction. Sustainability 4(7): 1371-1396.

Han MY, Chen GQ, Meng J et al. (2016) Virtual water accounting for a building construction engineering project with nine sub-projects: a case in E-town, Beijing. Journal of Cleaner Production 112(5): 4691-4700

Hong J, Shen GQ, Feng Y, Lau WS and Mao C (2015) Greenhouse gas emissions during the construction phase of a building: a case study in China. Journal of Cleaner Production 103(1): 249-259.

Hong J, Shen GQ, Guo S, Xue F and Zheng W (2016) Energy use embodied in China's construction industry: a multi-regional input-output analysis. Renewable and Sustainable Energy Reviews 53: 1303-1131.

Houser DL and Pruess H (2009) The effects of construction on water quality: a case study of the culverting of Abram Creek. Environmental Monitoring and Assessment 155(1-4): 431-442.

Huxham C and Vangen S (2003) Researching organizational practice through action research: case studies and design choices. Organizational Research Methods 6(3): 83-403.

Iddon CR and Firth SK (2013) Embodied and operational energy for new-build housing: a case study of construction methods in the UK. Energy and Buildings 67(1): 479-488.

ISB (Irish Statute Book) (1996) Waste Management Act 1996. Government Publications, Dublin, Ireland. See http://www. irishstatutebook.ie/1996/en/act/pub/0010/print.html (accessed 21/08/2020)

ISB (2001) Waste Management (Amendment) Act 2001. Government Publications, Dublin, Ireland. See http://www.irishstatutebook. ie/eli/2001/act/36/enacted/en/html (accessed 24/08/2020).

ISB (2003) Protection of the Environment Act 2003. Government Publications, Dublin, Ireland. See http://www.irishstatutebook. ie/eli/2003/act/27/enacted/en/html (accessed 24/08/2020).

Kabirifar K, Mojtahedi M, Wang C and Tam VWY (2020) Construction and demolition waste management contributing factors coupled with reduce, reuse, and recycle strategies for effective waste management: a review. Journal of Cleaner Production 263, https://doi.org/10.1016/j.jclepro.2020.121265.

Kelly M (2006) The Development of an Audit Methodology to Generate Construction Waste Production Indicators for the Irish Construction Industry. DPhil thesis, Department of Building and Civil Engineering at the Galway-Mayo Institute of Technology, Galway, Ireland.

Kelly M and Dowd D (2014) A Review of Design and Construction Waste Management Practices on Selected Case Studies - Lessons Learned, EPA STRIVE Programme Final Report. Environmental Protection Agency, Wexford, Ireland. See https://www.epa ie/pubs/reports/research/waste/research-report-146-for-web.pdf (accessed 13/08/2020).

Kelly M and Dowd D (2015) A Review of Design and Construction Waste Management Practices on Selected Case Studies: Lessons Learned, EPA Report 146. Environmental Protection Agency, Wexford, Ireland. See https://www.epa.ie/pubs/reports/research/waste/ research-report-146-for-web.pdf (accessed 25/08/2020).

Kelly M, Burke K and Gottsche J (2019) Exploring material circularity opportunities for a construction-SME on small-scale projects in Ireland. IOP Conference Series: Earth and Environmental Science 225: 012066

Knoeri C, Binder CR and Althuas HJ (2011) Decision on recycling: construction stakeholders' decisions regarding recycled mineral construction materials. Resources, Conservation and Recycling 55(11): 1039-1050.
Kofoworola OF and Gheewala SH (2009) Estimation of construction waste generation and management in Thailand. Waste Management 29(2): 731-738.

Li X, Zhu Y and Zhang Z (2010) An LCA-based environment impact assessment model for construction processes. Building and Environment 45(3): 766-775.

Lingard H, Graham P and Smithers G (2000) Employee perceptions of solid waste management systems in a large Australian contracting organisation: implications for company policy implementation. Construction Management and Economics 16(1): 383-393.

Liu Z, Osmani M, Demian P and Baldwin A (2015) A BIM-aided construction waste minimisation framework. Automation in Construction 59(1): 1-23.

Lu W, Webster C, Chen K, Zhang X and Chen X (2017) Computational building information modelling for construction waste management: moving from rhetoric to reality. Renewable and Sustainable Energy Reviews $\mathbf{6 8}$ 587-595.

McCormack MS, Treloar GJ, Palmowski L and Crawford RH (2007) Modelling direct and indirect water consumption associated with construction. Building Research Information 35(2): $156-162$.

Meng F, Liu G, Yang Z et al. (2016) Structural analysis of embodied greenhouse gas emissions from key urban materials: a case study of Xiamen City, China. Journal of Cleaner Production 6(1): 132-149.

Mujtaba IM, Edreder EA and Emtir M (2012) Significant thermal energy reduction in lactic acid production process. Applied Energy 89(1): $74-80$

Neilsen GH and Neilsen D (2006) Response of high-density apple orchards on coarse textured soil to form of potassium applied by fertigation's. Canadian Journal of Soil Science 86(4): 749-755.

Ooshaksaraie L (2011) An expert system applied in construction water quality monitoring. American Journal of Environmental Sciences 7(1): 75-81.

Osmani M (2012) Construction waste minimization in the UK: current pressures for change and approaches. Social and Behavioural Sciences 40(1): 37-40.

Osmani M, Glass J and Price A (2006) Architect and contractor attitudes to waste minimisation. Proceedings of the Institution of Civil Engineers - Waste and Resource Management 159(2): 65-72, https://doi.org/10.1680/warm.2006.159.2.65.

Paganin G, Angelotti A, Ducoli C et al. (2017) Energy performance of an exhibition hall in a life cycle perspective: embodied energy, operational energy and retrofit strategies. Energy Efficiency 10(6): 1343-1364

Poon CS (2007) Management of construction and demolition waste. Waste Management 27(2): 159-160.

Ramesh T, Prakash R and Shukla KK (2010) Life cycle energy analysis of buildings, an overview. Energy and Buildings 42(10): 1592-1600.

Raposo JR, Molinero J and Dafonte J (2010) Quantitative evaluation of hydrogeological impact produced by tunnel construction using water balance models. Engineering Geology 116(3-4): 323-332.

Rybka I, Bondar-Nowakowska E and Połoński M (2016) Causes and effects of adverse events during water supply and sewerage system constructions. Archives of Civil Engineering 62(1): 173-184.

Salcido JC, Raheem AA and Ravi S (2016) Comparison of embodied energy and environmental impact of alternative materials used in 
reticulated dome construction. Building and Environment 96(1): 22-34.

SCSI/PWC (Society of Chartered Surveyors Ireland/ PricewaterhouseCoopers) (2019) Construction Market Monitor 2019. Society of Chartered Surveyors, Dublin, Ireland. See https://www.pwc.ie/publications/2019/scsi-pwc-construction-marketmonitor-2019.pdf (accessed 13/08/2020).

SEAI (Sustainable Energy Authority of Ireland) (2020) See https://www. seai.ie (accessed 13/10/2020).

Stephan A and Crawford R (2014) A comprehensive life cycle water analysis framework for residential buildings. Building Research and Information 42(6): 685-695.

Susman G and Evered R (1978) An assessment of the scientific merits of action research. Administrative Science Quarterly 23(4): 582-603.

Taggart M, Dosela L and Rooke J (2014) The role of the supply chain in the elimination and reduction of construction rework and defects: an action research approach. Construction Management and Economics 32(7/8): 829-842.

Tam VWY (2008) On the effectiveness in implementing a waste-management-plan method in construction. Waste Management 28(6): 1072-1080.
Ueda T, Roberts ES, Norton A et al. (2019) A life cycle assessment of the construction phase of eleven micro-hydropower installations in the UK. Journal of Cleaner Production 218: 1-9.

UN (United Nations) (2015) Paris Agreement. United Nations, Paris, France. See https://bit.ly/34yN1OV (accessed 24/08/2020)

Woroniak G and Piotrowska JW (2014) Effects of pollution reduction and energy consumption reduction in small churches in Drohiczyn community. Energy and Buildings 72(1): 51-61.

Wrap (Waste and Resources Action Programme) (2015) The Business Case for Resource Efficiency: Contractors. Waste and Resources Action Programme, Banbury, England. See https://bit.ly/2CLH4T1 (accessed 21/08/2020).

Wrap (2020) See https://wrap.org.uk/ (accessed 07/10/2020).

Xu J, Shi Y, Xie Y and Zhao S (2019) A BIM-based construction and demolition waste information management system for greenhouse gas quantification and reduction. Journal of Cleaner Production 229: 308-324.

Yuan $\mathrm{H}$ and Shen $\mathrm{L}$ (2011) Trend of research on construction and demolition waste management. Waste Management 31(4) 670-679

\section{How can you contribute?}

To discuss this paper, please email up to 500 words to the editor at journals@ice.org.uk. Your contribution will be forwarded to the author(s) for a reply and, if considered appropriate by the editorial board, it will be published as discussion in a future issue of the journal.

Proceedings journals rely entirely on contributions from the civil engineering profession (and allied disciplines). Information about how to submit your paper online is available at www.icevirtuallibrary.com/page/authors, where you will also find detailed author guidelines. 